\title{
Growth/Differentiation Factor 15
}

National Cancer Institute

\section{Source}

National Cancer Institute. Growth/Differentiation Factor 15. NCI Thesaurus. Code C34026.

Growth/differentiation factor 15 (308 aa, 34 kDa) is encoded by the human GDF15 gene. This protein plays a role in both tissue differentiation and signal transduction. 